\section{JAVNE FINANCIJ}

\title{
Učinci predloženih promjena u porezu na dohodak na životni standard građana
}

\section{mr. sc. Ivica Urban}

Ministarstvo financija predlaže mjere ekonomske politike kojima bi se ublažile posljedice rasta cijena hrane i energenata na standard stanovništva. Jedna od mjera trebala bi biti subvencioniranje građana i poduzeća, a druga je usmjerena na promjene u poreznom sustavu, konkretnije na povećanje osobnih odbitaka i poreznih razreda u sustavu poreza na dohodak. Cilj nam je odgovoriti na pitanje: Koliko će najavljena mjera povećati raspoloživi dohodak građana?

Treba li država uvoditi mjere kompenziranja cjelokupnog stanovništva u slučaju rasta cijena nekih proizvoda? Ne, stav je autora. Rast cijena hrane i energenata posljedica je neravnoteža na globalnom tržištu i na to ne možemo utjecati. Većina građana prilagodit će se rastu cijena "nužnih" proizvoda tako što će smanjiti kupnje nekih drugih, "manje nužnih" proizvoda. Najugroženijima, odnosno onima koji su si jedva mogli priuštiti "nužna" dobra i prije poskupljenja, država može dodatno pomoći u okviru postojećih ciljanih instrumenata socijalne pomoći jer je iz analize koja slijedi vidljivo da se njima putem sustava poreza na dohodak ne može pomoći.

Kako onda država može pomoći u okruženju rastućih cijena hrane i energenata? Jednostavno - nastavkom započetih procesa privatizacije i liberalizacije, ukidanjem subvencija i zakonskih monopola povlaštenim poduzećima, smanjivanjem poreza/rashoda i općenito povlačenjem iz gospodarskog područja. Svime time povećava se konkurencija na tržištu, a zatim investicije i proizvodnja što rezultira smanjenjem cijena dobara i usluga. Veća privatna inicijativa također će pojačati fleksibilnost gospodarstva i sposobnost prilagodbe promjenama u globalnom okruženju.

Treba li država snižavati poreze? Država bi morala snižavati ukupno porezno opterećenje, ali ono mora biti praćeno odgovarajućim smanjenjem rashoda. Proces 
smanjenja poreza i rashoda u ukupnom BDP-u treba biti postupan i trajan, neovisan o tzv. dnevno-političkim razmatranjima i ad hoc odlukama.

Godine 2005. detaljno smo opisali očekivane učinke tadašnjeg novog zakona o porezu na dohodak na životni standard različitih dohodovnih skupina. ${ }^{1}$ Neki od zaključaka tog rada bili su:

* Porez na dohodak u Hrvatskoj izrazito je progresivan, što se moglo uočiti i iz činjenice da je 10\% obveznika s najvišim dohocima plaćalo dvije trećine ukupnog poreza na dohodak.

* Povećanje osobnog odbitka ne može biti mjera povećanja standarda pojedinaca bez oporezivog dohotka i onih s niskim dohocima (čiji je dohodak manji od postojećeg osobnog odbitka).

Ovaj put nudimo sličnu analizu temeljenu na podacima iz Ankete o potrošnji kućanstava (APK) za 2006. godinu. ${ }^{2}$ Kućanstva iz uzorka prvo smo poredali prema godišnjem raspoloživom dohotku po članu kućanstva, a zatim smo ih svrstali u pet skupina s jednakim brojem pojedinaca (kvintilne skupine). Tablica 1 prikazuje prosječne vrijednosti različitih stavki po članu kućanstva. Neoporezivi dohodak (u stupcu 1) je sav dohodak koji se ne oporezuje porezom na dohodak (mirovine iz inozemstva, socijalne naknade, dohodak od štednje, proizvodnja za vlastite potrebe, transferi od drugih osoba). Oporezivi dohodak (u stupcu 2) je dohodak koji podliježe porezu na dohodak. Stupac 3 prikazuje koliko u prosjeku godišnje poreza i prireza snosi član kućanstva prema sadašnjim odredbama. ${ }^{3}$ Raspoloživi dohodak (u stupcu 4) je zbroj neoporezivog i oporezivog dohotka umanjen za porez na dohodak i prirez. Stupac 5 prikazuje iznose poreza i prireza dobivene simulacijom uz korištenje budućih parametara - osnovnog osobnog odbitka od 1.800 kuna mjesečno i 3.200 kuna za umirovljenike. ${ }^{4}$ Zadnji stupac u Tablici 1 prikazuje razliku između "sadašnjeg" i „budućeg" iznosa poreza i prireza.

Prva kvintilna skupina predstavlja petinu stanovnika s najnižim raspoloživim dohocima. Ta skupina zahvaljujući sadašnjem osobnom odbitku gotovo da ne plaća porez na dohodak i prirez, već prosječno tek 21 kunu godišnje po članu kućanstva (stupac 3). U slučaju novog, povećanog osnovnog osobnog odbitka, prosječni porez i prirez iznosili bi 15 kuna po članu kućanstva (stupac 5), odnosno 6 kuna manje (stupac 6). Međutim, godišnje

\footnotetext{
${ }^{1}$ Analiza je prikazana u Newsletteru br. 18 Instituta za javne financije.

2 Institut za javne financije izrađuje mikrosimulacijski model koji na temelju raspoloživih podataka iz APK (koju provodi Državni zavod za statistiku) i zadanih parametara izračunava iznose poreza na dohodak i prireza za svakog pojedinca iz uzorka. Ovdje je model upotrijebljen kako bi se izračunale porezne obveze u dva sustava: sadašnjem i predloženom (www.vlada.hr).

${ }^{3} \mathrm{Uz}$ osobni odbitak za umirovljenike do 3.000 kuna mjesečno i osnovni osobni odbitak od 1.600 kuna za ostale obveznike, osim onih koji žive na područjima posebne državne skrbi i brdsko-planinskim područjima.

${ }^{4}$ Proporcionalno se povećavaju osobni odbici za djecu i uzdržavane članove jer se faktori osobnog odbitka sada množe povećanim osnovnim osobnim odbitkom od 1.800 kuna. Granice poreznih razreda također se proporcionalno povećavaju.
} 
smanjenje poreza i prireza niti za ostale kvintilne skupine ne bi bilo značajno, te se kreće od 55 kuna za 2. kvintilnu skupinu do 526 kuna po članu kućanstva iz 5. kvintilne skupine.

Tablica 1. Prosječni godišnji iznosi dohotka i poreza po članu kućanstva, u kunama, 2006.

\begin{tabular}{|c|c|c|c|c|c|c|}
\hline $\begin{array}{c}\text { Kvintilna } \\
\text { skupina }\end{array}$ & $\begin{array}{c}\text { Neoporezivi } \\
\text { dohodak }\end{array}$ & $\begin{array}{c}\text { Oporezivi } \\
\text { dohodak }\end{array}$ & $\begin{array}{c}\text { Porez na } \\
\text { dohodak } \mathbf{i} \\
\text { prirez } \\
\text { (sadašnje } \\
\text { odredbe) }\end{array}$ & $\begin{array}{c}\text { Raspoloživi } \\
\text { dohodak }\end{array}$ & $\begin{array}{c}\text { Porez na } \\
\text { dohodak } \mathbf{i} \\
\text { prirez } \\
\text { buduće } \\
\text { odredbe) }\end{array}$ & $\begin{array}{c}\text { Smanjenje } \\
\text { porezne } \\
\text { obveze }\end{array}$ \\
\hline $\mathbf{1 .}$ & $\mathbf{1}$ & $\mathbf{2}$ & $\mathbf{3}$ & $\mathbf{4 = 1 + 2 - 3}$ & $\mathbf{5}$ & $\mathbf{6 = 3 - 5}$ \\
\hline $\mathbf{2 .}$ & 2.975 & 7.485 & 21 & 10.439 & 15 & 6 \\
\hline $\mathbf{3 .}$ & 3.190 & 14.217 & 186 & 16.848 & 131 & 55 \\
\hline $\mathbf{4 .}$ & 3.530 & 27.123 & 1.455 & 29.198 & 1.244 & 211 \\
\hline $\mathbf{5 .}$ & 5.191 & 46.782 & 5.747 & 46.226 & 5.221 & 526 \\
\hline
\end{tabular}

Izvor: autorov izračun na temelju Ankete o potrošnji kućanstava iz 2006. i uz pomoć mikrosimulacijskog modela

Tablica 2 prikazuje prosječne godišnje iznose ukupne osobne potrošnje po članu kućanstva (u stupcu 2), i zasebno potrošnju na hranu i gorivo (u stupcima 3 i 4). Zamislimo da se dogodi jednokratno povećanje cijena goriva i hrane od $10 \%$, a da ljudi ne promijene količine kupljenih dobara. Stupac 5 prikazuje povećanje godišnjih izdataka za gorivo i hranu uslijed takvog rasta cijena. Sada se pitamo: "Koliki će dio povećanja izdataka na gorivo i hranu kompenzirati država smanjenjem poreznog tereta?"

Tablica 2. Prosječni godišnji iznosi dohotka i potrošnje po članu kućanstva, u kunama, 2006.

\begin{tabular}{|c|c|c|c|c|c|c|c|}
\hline $\begin{array}{c}\text { Kvintilna } \\
\text { skupina }\end{array}$ & $\begin{array}{c}\text { Raspoloživi } \\
\text { dohodak }\end{array}$ & $\begin{array}{c}\text { Osobna } \\
\text { potrošnja } \\
- \text { ukupno }\end{array}$ & $\begin{array}{c}\text { Izdaci } \\
\text { za } \\
\text { hranu }\end{array}$ & $\begin{array}{c}\text { Izdaci } \\
\text { za } \\
\text { gorivo }\end{array}$ & $\begin{array}{c}\text { Rast izdataka } \\
\text { za hranu i } \\
\text { gorivo uslijed } \\
\text { 10-postotnog } \\
\text { povećanja } \\
\text { cijena }\end{array}$ & $\begin{array}{c}\text { Smanjenje } \\
\text { porezne } \\
\text { obveze }\end{array}$ & $\begin{array}{c}\text { Kompenzacija } \\
\text { (\%) }\end{array}$ \\
\hline $\mathbf{1 .}$ & $\mathbf{1}$ & $\mathbf{2}$ & $\mathbf{3}$ & $\mathbf{4}$ & $\mathbf{5 = ( 3 + 4 ) \times 1 0 \%}$ & $\mathbf{6}$ & $\mathbf{7 = 6 / 5 \times 1 0 0 \%}$ \\
\hline $\mathbf{2 .}$ & 10.439 & 14.369 & 5.532 & 571 & 610 & 6 & 1 \\
\hline $\mathbf{3 .}$ & 22.389 & 18.584 & 6.538 & 837 & 737 & 55 & 7 \\
\hline $\mathbf{4 .}$ & 29.198 & 26.746 & 7.022 & 1.115 & 814 & 133 & 16 \\
\hline $\mathbf{5 .}$ & 46.226 & 36.441 & 8.693 & 1.466 & 930 & 211 & 23 \\
\hline
\end{tabular}

Izvor: autorov izračun na temelju Ankete o potrošnji kućanstava iz 2006., i uz pomoć mikrosimulacijskog modela

Izdaci prve kvintilne skupine porasli bi 610 kuna, ali bi njihova kompenzacija zahvaljujući smanjenju poreza na dohodak iznosila 6 kuna, odnosno samo 1\% povećanih izdataka (stupac 7). Relativno male kompenzacije ostvarile bi i sljedeće tri kvintilne skupine, od 7 do $23 \%$ poraslih izdataka. U slučaju 10-postotnog povećanja cijena godišnji izdaci za hranu i gorivo pete kvintilne skupine u prosjeku bi se povećali za 1.055 kuna dok bi smanjenje porezne obveze iznosilo 526 kuna, što znači da bi im bilo nadoknađeno 50\% 
gubitka uzrokovanog 10-postotnim rastom cijena. Stupanj kompenzacije raste s dohotkom (stupac 7), ali za većinu stanovništva je prilično skroman.

\section{Zaključak}

Sniženje tereta poreza na dohodak smanjenjem porezne osnovice ne utječe na dohodak pojedinaca s najnižim dohocima i ne može im donijeti gotovo nikakav probitak u smislu boljeg životnog standarda. Toj skupini stanovništva država može posebno pomoći u okviru ciljanih instrumenata socijalne pomoći.

Predložena mjera smanjenja poreza donekle će povećati raspoloživi dohodak većine građana i olakšati posljedice "cjenovnog udara". No, treba ustrajati na daljnjim smanjenjima poreznog tereta, također i smanjenjem stopa u sustavu poreza na dohodak i drugih poreza u okviru smanjivanja javnih rashoda. Do sniženja poreza ne treba dolaziti samo povodom rasta cijena "nužnih" proizvoda, već to treba biti neovisan, višegodišnji osmišljeni proces prilagodbe fiskalnog sustava. 